\title{
Effect of Piperine in Combination with Gamma Radiation on A549 Cells
}

\author{
Koniyan Shaheer ${ }^{1} \quad$ M. Divya Lakshmanan ${ }^{1}$ \\ ${ }^{1}$ Molecular Biology Division, Yenepoya Research Centre, Yenepoya \\ (Deemed to be University), Deralakatte, Mangalore, Karnataka, \\ India
}

J Health Allied Sci Nu:2021;11:80-86

\begin{abstract}
Address for correspondence M. Divya Lakshmanan, PhD, Molecular Biology Division, Yenepoya Research Centre, Yenepoya (deemed to be University), Deralakatte, Mangalore, Karnataka 575018, India (e-mail: divyalmangalath@gmail.com,divya@yenepoya.edu.in).
\end{abstract}

\begin{abstract}
Keywords

- lung cancer

- piperine

- radiosensitization

- CompuSyn analysis

Background Lung cancer is a major constrain that increases mortality globally. Radiotherapy is one of the treatment modalities against lung cancer. A high dose of targeted radiation is required to achieve the treatment efficacy of cell killing. After radiotherapy, eventual tumor progression and therapy resistance are still a consequence of patient who undertakes nonsurgical radiation therapy. Piperine, a plant alkaloid, has been known to enhance the action of the anticancer drugs in various drug-resistant cancer cells. The aim of the current in vitro study was to study the effect of piperine on radiosensitizing property against A549 cells.

Methods In vitro radiosensitizing activity of piperine was elucidated on A549 cells using MTT (3-(4, 5-dimethylthiazol-2-yl)-25-diphenyltetrazolium bromide) assay. CompuSyn analysis was used to compute the combination index values to analyze the combinatory effect of piperine and radiation

Results and Conclusion We observed that piperine increased tumor cell killing in combination with the $\gamma$-radiation in vitro. However, further studies are warranted to understand the molecular mechanism of the radiosensitizing action of piperine.
\end{abstract}

\section{Introduction}

The poor prognosis of patients with lung cancer is the major cause of cancer-related deaths. ${ }^{1}$ According to GLOBOCAN 2018, lung cancer has the highest incidence rate and mortality rate. ${ }^{2}$ Though the radiotherapy is a main treatment modality against lung cancer, gradual development of therapy resistance and cancer recurrence is a major constrain. ${ }^{3}$ Intensive attempts to improve the outcome of radiotherapy treatment have been a remarkable challenge. One of the few achievable therapeutic strategies of lung cancer to increase the treatment efficacy demonstrated that the combination of radiosensitizer with radiation produces a significant decrease in mortality compared with irradiation group. ${ }^{4}$ Because these studies use a relatively low dose of radiation and demonstrated a reduced effect on the occurrence of caner metastases and secondary cancer, the improvement realized by the use of radiosensitizer in therapy probably due to radiosensitization. ${ }^{4-6}$ Thus, the discovery of a potent radiosensitizer against lung cancer could improve the outcome of treatment of this disease.

A most important concern about radiotherapy is that it acquires resistance by activating several alternating signaling pathways that elicit cancer and/or enhanced DNA repair pathways. Radiotherapy resistance, defined as a poor prognosis in the effectiveness of radio therapy, is a major hindrance in cancer treatment. In such cases, combinatorial approach is an effective way to augment treatment efficacy. Combinatory approach often follows three main strategies: published online

February 10, 2021
DOI https://doi.org/

$10.1055 / \mathrm{s}-0040-1722808$ ISSN 2582-4287.
(C) 2021. Nitte (Deemed to be University).

This is an open access article published by Thieme under the terms of the Creative Commons Attribution-NonDerivative-NonCommercial-License, permitting copying and reproduction so long as the original work is given appropriate credit. Contents may not be used for commercial purposes, or adapted, remixed, transformed or built upon. (https://creativecommons.org/licenses/by-nc-nd/4.0/).

Thieme Medical and Scientific Publishers Pvt. Ltd. A-12, 2nd Floor, Sector 2, Noida-201301 UP, India 
(1) inhibition of possible alternative pathways, (2) targeting of the single pathway to accomplish downregulation or inhibition, or (3) targeting and downregulation or inhibition of two different pathways will lead to synergistic action on radiosensitization. ${ }^{7}$

Phytocompounds or natural based combinatorial approach may serve in the development of anticancer agents with minimal side effects and better efficacy. ${ }^{8-11}$ In addition, natural compounds because of their antioxidant and anti-inflammatory effects have better effects as radiation protectors for healthy cells. ${ }^{12}$ Some natural radiosensitizers are danshensu, curcumin, wortmannin, genistein, and quercetin. ${ }^{13-18}$ Piper nigrum Linn commonly known as black pepper belongs to the spices widely consumed by a great number of people worldwide. Piperine is a bioactive compound and key alkaloid, present in Piper nigrum Linn and Piper longum Linn (long pepper). It has been found that piperine enhances the action of the anticancer drugs in various drug-resistant cancer cells. ${ }^{19-23}$ Studies regarding the radiosensitizing effect of piperine on lung cancer are yet to be done. Combination index (CI) is a theorem of Chou-Talalay that defines quantitative explanation for additive effect ( $\mathrm{Cl}$ " $=1$ ), synergism ("Cl" $<1$ ), and antagonism ("Cl" > 1) in drug combinations studies. This theory also explains algorithms for computer-based model for synergistic and/or antagonistic mechanism at any dose level and effect through isobologram and CI plot respectively. ${ }^{24}$ As there is a need to develop a potent therapy to treat lung cancer, our study aimed to explore the effect of piperine pretreatment and to improve radiotherapy treatment on lung cancer cells and interpret its mechanism of action.

\section{Materials and Methods}

The phytocompound piperine ( $>97 \%$ ) and dimethyl sulfoxide (DMSO) were procured from Sigma-Aldrich, India. Cell culture reagents such as Dulbecco's Modified Eagles Medium (DMEM), fetal bovine serum (FBS), penicillin and streptomycin solution, L-glutamine, Trypan blue dye, 3-(4, 5-dimethylthiazol-2-yl)-25-diphenyltetrazolium bromide (MTT), and other chemicals (analytical or molecular biology grade) were procured from HiMedia, India.

\section{Cell Culture}

Human lung adenocarcinoma cell line-A549 (NCCS, Pune, India) was cultured in culture media (DMEM), supplemented with FBS (10\%), penicillin, and streptomycin (1\%) and $2 \mathrm{mM}$ L-glutamine. The cells were maintained at $37^{\circ} \mathrm{C}$ in a $5 \%$ $\mathrm{CO}_{2}$ humidified atmospheric conditions.

\section{Dose Optimization of Piperine on A549 Cells}

Dose optimization of piperine was done using MTT assay. ${ }^{25,26}$ Briefly, A549 cells $\left(3 \times 10^{3}\right.$ cells/well) were seeded into 96-well plate and incubated 24 hours at normal culture conditions. Piperine dissolved in DMSO was taken at concentrations of 10 to $100 \mu \mathrm{g} / \mathrm{mL}$ and was added into the culture plates and incubated for 48 hours and then MTT assay was performed. The optical density readings at $570 \mathrm{~nm}$ were taken using the multimode plate reader (FLUOstar Omega, Mumbai, India). The experiment was performed in triplicates. The final DMSO concentration in the treatment was kept within $0.1 \%$.

\section{Dose Optimization of Ionizing Gamma Radiation on A549 Cells}

A549 cells were exposed to ionizing gamma $(\gamma)$-radiation (IR) at a dose ranging from 1.25 to $10 \mathrm{~Gy}$, using a low-dose gamma irradiator-2000 (BRIT, Mumbai, India), with ${ }^{60}$ Co source as irradiator and $10.3 \mathrm{~Gy} / \mathrm{min}$ deliverable dose rate. MTT cell proliferation assay was performed after 48 hours of incubation. ${ }^{25,26}$

\section{Cytotoxicity Assessment Using MTT Cell Proliferation Assay}

The two doses of piperine (low dose: 12.5 and high dose: $25 \mu \mathrm{g} / \mathrm{mL}$ ) were added to A549 cells in individual flasks, 2 hours before to $\gamma$-radiation treatment $(1.25 \mathrm{~Gy})$ and incubated at normal culture condition for 48 hours as described previously. ${ }^{26}$ Cells (vehicle control) kept in the chamber but not irradiated were considered as sham control. After 48 hours of incubation, the cytotoxic effect of piperine and $\gamma$-radiation on A549 cells was evaluated by MTT cell proliferation assay as mentioned earlier. ${ }^{25}$

Percentageof cell viability $=\frac{(\text { No. of viable cells in control }- \text { No. viable cell in test })}{\text { No. of viable cells in control }} \times 100$

\section{CompuSyn Analysis to Check the Synergistic Effect of the Combination Treatment}

CompuSyn software (ComboSyn, Inc., Paramus, NJ, United States) was used to quantitatively depict the mechanistic effect of the combination treatment. The data from the cytotoxicity studies were taken to compute $\mathrm{CI}$ values, CI plot, dose response curve, and normalized isobologram. $\mathrm{CI}$ values were used to analyze the synergism ("CI" $<1$ ), additive effect ( $\mathrm{Cl}$ " $=1$ ) and/or antagonism ( $\mathrm{Cl}$ " $<1$ ) of the co-treatment. ${ }^{24,27}$

The $\mathrm{Cl}$ is calculated by using the formula:

$$
C I=\frac{d 1}{D X 1}+\frac{d 2}{D X 2} C I
$$

Where Dx1 indicates, the dose of test agent 1 ( $\gamma$-radiation) needed to decrease " $x$ " percentage of proliferation alone, and $\mathrm{d} 1$ indicates the dose of test agent 1 needed to decrease " $\mathrm{x}$ " percentage of proliferation along with $\mathrm{d} 2$ treatment. Similarly, Dx2 indicates the dose of test agent 2 (piperine) needed to decrease " $x$ " percentage of proliferation alone, and $\mathrm{d} 2$ indicates the dose of test agent 2 needed to decrease " $\mathrm{x}$ " percentage of proliferation along with $\mathrm{d} 1$.

\section{Morphological Analysis}

A549 cells at a cell density of $0.35 \times 10^{6}$ cells $/ \mathrm{mL}$ were seeded into $35 \mathrm{~mm}$ dishes. After 24 hours of incubation, the cells were pretreated with piperine for 2 hours and then irradiated with $\gamma$-radiation. The cells that are untreated with piperine and 
nonirradiated were taken as control. The changes in the cell morphology were observed using inverted light microscope (Zeiss Primo Vert, Mumbai, India) at a magnification of 40×.

\section{Statistical Analysis}

Data were represented as mean \pm standard deviation. Data analysis was done using one-way analysis of variance using GraphPad PRISM version 7.0. A $p$-value $<0.0001$ was scored significant.

\section{Results}

\section{Effect of Piperine and Gamma Radiation on Cell Viability or Cell Proliferation}

MTT cell proliferation assay is used to check the effect of piperine and $\gamma$-radiation on A549 cell proliferation or cell viability indirectly that measures mitochondrial succinate dehydrogenase activity spectrophotometrically. Inhibition of A549 cell proliferation against piperine was in a dose-dependent manner ( - Fig. 1A) and A549 cells show high resistance toward $\gamma$-radiation of selected dose ranging from 1.25 to $10 \mathrm{~Gy}$. Cell killing was less than 40\% (33-37\%) even at $10 \mathrm{~Gy}$ (-Fig. 1B).

\section{Piperine Synergistically Enhances Radiation-Induced Cell Death on A549 Cells}

To analyze piperine could sensitize A549 cells to $\gamma$-radiation treatment (IR), two doses of piperine (low dose: 12.5 and high dose: $25 \mu \mathrm{g} / \mathrm{mL}$ ) were added to A549 cells in individual flasks 2 hours before to $\gamma$-radiation treatment ( $1.25 \mathrm{~Gy}$ ) and incubated at normal culture conditions for 48 hours. We found that piperine treatment combined with $\gamma$-radiation exhibited enhanced inhibition of cell proliferation ( $55 \%)$ compared with individual $\gamma$-radiation/piperine treatment alone ( - Fig. 1C). Significant difference among various treatment groups in the observed cytotoxicity is given in - Table $\mathbf{1}$. To study whether the radiosensitization finding of the combination treatment action is synergistic

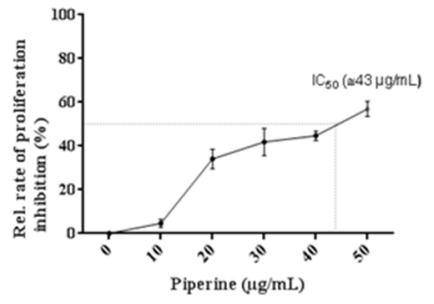

A

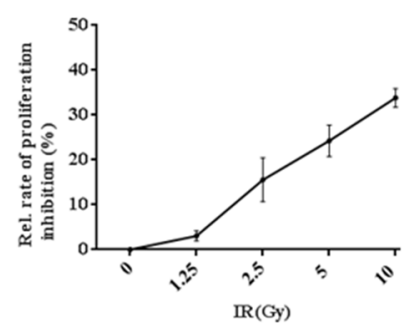

B

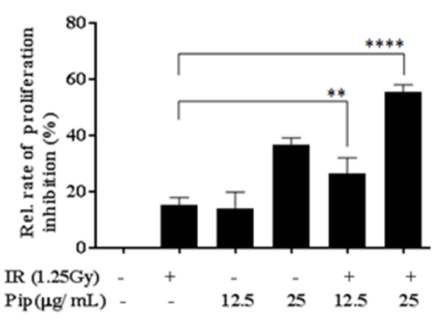

C

Fig. 1 Radiosensitization effect of piperine on A549 cells. (A) Optimization of piperine dose. Piperine was taken at different concentrations 10 to $100 \mu \mathrm{g} / \mathrm{mL}$ and 3-(4, 5-dimethylthiazol-2-yl)-25-diphenyltetrazolium bromide (MTT) assay was performed on A549 cells. DMSO treated cells were used as vehicle control. (B) Optimization of $\gamma$-radiation dose. (C) Relative cell proliferation inhibition analysis after combination treatment with piperine and $\gamma$-radiation by MTT assay on A549 cells. Data was represented as mean \pm standard deviation. IR, ionizing gamma radiation; Pip, piperine.

Table 1 Multiple comparison analysis of MTT cell proliferation assay of combination experiment by post-ANOVA Bonferroni's multiple comparisons test

\begin{tabular}{|c|c|c|}
\hline Comparisons among groups & Significance & $\begin{array}{l}\text { Adjusted } \\
p \text {-Value }\end{array}$ \\
\hline Sham versus IR ( $\mathrm{\gamma})$ & $* * *$ & 0.0002 \\
\hline Sham versus Pip $(12.5 \mu \mathrm{g} / \mathrm{mL})$ & $* * *$ & 0.0007 \\
\hline Sham versus Pip $(25 \mu \mathrm{g} / \mathrm{mL})$ & $* * * *$ & $<0.0001$ \\
\hline Sham versus $I R(\gamma)+P i p(12.5 \mu \mathrm{g} / \mathrm{mL})$ & $* * * *$ & $<0.0001$ \\
\hline Sham versus IR(Y)+Pip $(25 \mu \mathrm{g} / \mathrm{mL})$ & $* * * *$ & $<0.0001$ \\
\hline IR $(\mathrm{Y})$ versus Pip $(12.5 \mu \mathrm{g} / \mathrm{mL})$ & ns & $>0.9999$ \\
\hline IR $(\gamma)$ versus Pip $(25 \mu \mathrm{g} / \mathrm{mL})$ & $* * * *$ & $<0.0001$ \\
\hline IR $(\gamma)$ versus IR(Y) +Pip $(12.5 \mu \mathrm{g} / \mathrm{mL})$ & $* *$ & 0.0066 \\
\hline IR $(\mathrm{\gamma})$ versus IR(Y)+Pip $(25 \mu \mathrm{g} / \mathrm{mL})$ & $* * * *$ & $<0.0001$ \\
\hline $\operatorname{Pip}(12.5 \mu \mathrm{g} / \mathrm{mL})$ versus Pip $(25 \mu \mathrm{g} / \mathrm{mL})$ & $* * * *$ & $<0.0001$ \\
\hline $\operatorname{Pip}(12.5 \mu \mathrm{g} / \mathrm{mL})$ versus IR(Y) +Pip $(12.5 \mu \mathrm{g} / \mathrm{mL})$ & ** & 0.0019 \\
\hline $\operatorname{Pip}(12.5 \mu \mathrm{g} / \mathrm{mL})$ versus IR(Y)+Pip $(25 \mu \mathrm{g} / \mathrm{mL})$ & $* * * *$ & $<0.0001$ \\
\hline 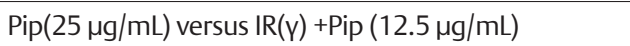 & $* * * *$ & $<0.0001$ \\
\hline $\operatorname{Pip}(25 \mu \mathrm{g} / \mathrm{mL})$ versus $I R(\gamma)+\operatorname{Pip}(25 \mu \mathrm{g} / \mathrm{mL})$ & NS & 0.0801 \\
\hline $\mathrm{IR}(\mathrm{\gamma})+\operatorname{Pip}(12.5 \mu \mathrm{g} / \mathrm{mL})$ versus IR( $(\mathrm{\gamma})+\operatorname{Pip}(25 \mu \mathrm{g} / \mathrm{mL})$ & $* * * *$ & $<0.0001$ \\
\hline
\end{tabular}

Abbreviations: ANOVA, analysis of variance; $\mathrm{Cl}$, confidence interval; IR( $\gamma$ ), ionizing gamma radiation; MTT, 3-(4, 5-dimethylthiazol-2-yl)-25-diphenylte trazolium bromide; Pip, piperine. 
or additive, we computed the $\mathrm{CI}$ values and plotted $\mathrm{CI}$ plot isobologram for the two selected concentrations of piperine (low dose: 12.5 and high dose: $25 \mu \mathrm{g} / \mathrm{mL}$ ) against exposed $1.25 \mathrm{~Gy}$ of $\gamma$-radiation using freely available CompuSyn software. This study was designed to analyze the nature of the effects of combination treatment.

A dose response curve for piperine and $\gamma$-radiation was generated as given in - Fig. 2A, D. Synergism effect is higher than an additive and antagonism effect. As represented in the CI plots ( - Fig. 2B, E) and isobologram ( - Fig. 2C, F), the calculated $\mathrm{CI}$ values were less than 1 for the combination treatments (IR + Pip $12.5 \mu \mathrm{g} / \mathrm{mL}$ and IR + Pip $25 \mu \mathrm{g} / \mathrm{mL}$ ). This clearly demonstrates a synergistic effect. Surprisingly, all the values (values computed from triplicate experiments) in the isobologram ( $\mathbf{F i g}$. 2C, F) generated for the two selected concentrations of piperine (low dose: 12.5 and high dose: $25 \mu \mathrm{g} / \mathrm{mL}$ ) with $\gamma$-radiation $1.25 \mathrm{~Gy}$ showed well within the stipulated region of synergism. CI points of each combination study are shown in - Tables $\mathbf{2}$ and 3, respectively. Our findings from these results show that pretreatment with piperine efficiently sensitized A549 cells toward cell killing effects of $\gamma$-radiation, compared with a single regime treatment.

\section{Cellular Morphological Analysis}

Morphological assessment showed that piperine pretreatment in combination with $\gamma$-radiation increased the cell death considerably when compared with A549 cells treated with piperine $/ \gamma$-radiation alone ( $\boldsymbol{- \text { Fig. }} \mathbf{3})$.

As given in - Fig. 3, the control (A) exhibited colony features of A549 lung cancer morphology, while cells pretreated with piperine followed by $\gamma$-radiation ( - Fig. 3E, F) showed

Table $2 \mathrm{Cl}$ data for combination of IR+Pip $12.5 \mu \mathrm{g} / \mathrm{mL}$

\begin{tabular}{|l|l|l|l|}
\hline $\mathrm{IR}(\gamma)(\mathrm{Gy})$ & Piperine $(\boldsymbol{\mu g} / \mathrm{mL})$ & Effect & $\mathrm{CI}$ \\
\hline 1.25 & 12.5 & 0.79 & 0.97832 \\
\hline 1.25 & 12.5 & 0.75 & 0.84384 \\
\hline 1.25 & 12.5 & 0.71 & 0.73908 \\
\hline 1.25 & 12.5 & 0.67 & 0.65425 \\
\hline
\end{tabular}

Abbreviations: $\mathrm{Cl}$, combination index; $\mathrm{IR}(\gamma)$, ionizing gamma radiation; Pip, piperine.

Table $3 \mathrm{Cl}$ data for combination of IR+Pip25 $\mu \mathrm{g} / \mathrm{mL}$

\begin{tabular}{|l|l|l|l|}
\hline $\mathbf{I R}(\gamma)(\mathrm{Gy})$ & Piperine $(\boldsymbol{\mu g} / \mathrm{mL})$ & Effect & $\mathrm{Cl}$ \\
\hline 1.25 & 25.0 & 0.44 & 0.63135 \\
\hline 1.25 & 25.0 & 0.45 & 0.64766 \\
\hline 1.25 & 25.0 & 0.41 & 0.58435 \\
\hline 1.25 & 25.0 & 0.47 & 0.68139 \\
\hline
\end{tabular}

Abbreviations: $\mathrm{Cl}$, combination index; $\mathrm{IR}(\gamma)$, ionizing gamma radiation; Pip, piperine.

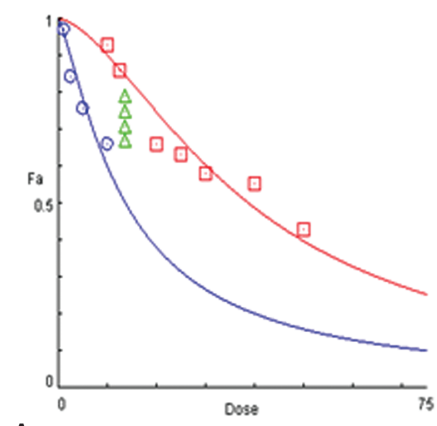

A
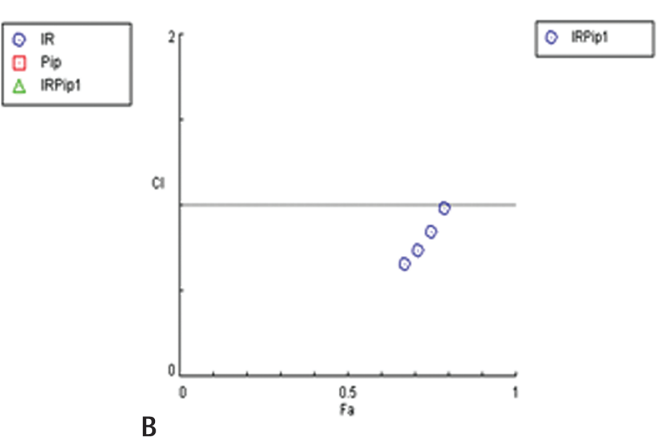

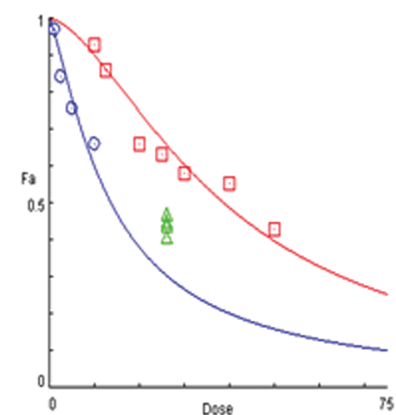

D
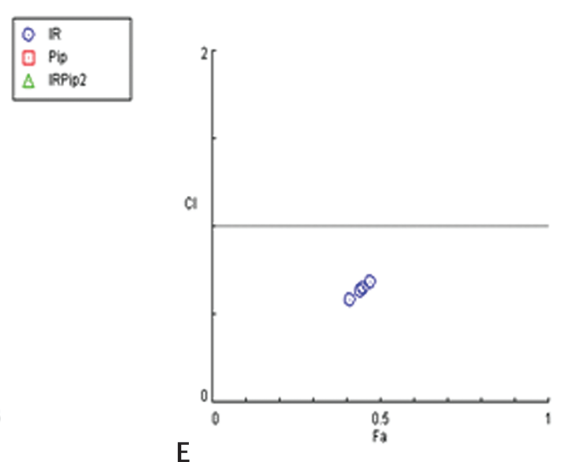

E

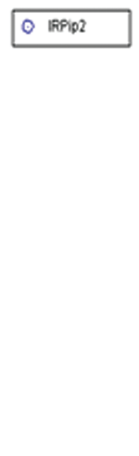

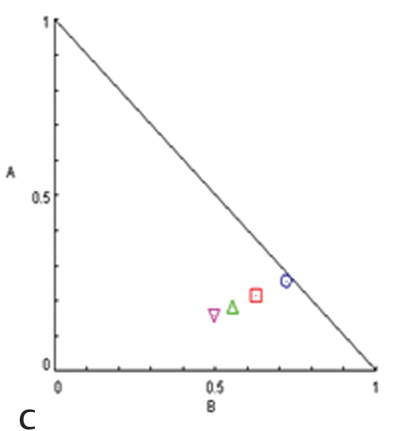

O. Point1

a Point 2

$\Delta$ Point

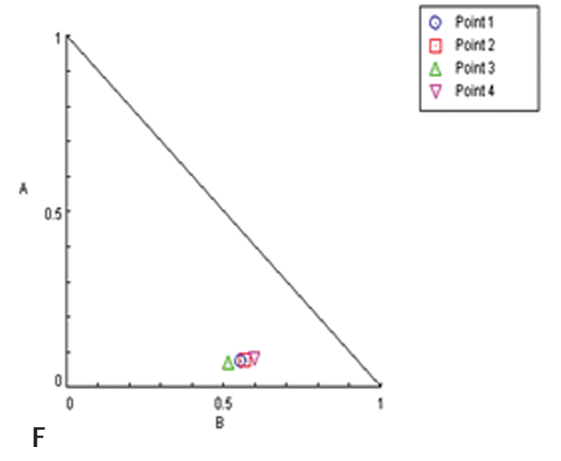

Fig. 2 CompuSyn analysis to determine the synergistic effect of the piperine and $\gamma$-radiation on A549 cells. (A) Dose response curve of piperine (Pip) and IR (ionizing $\gamma$-radiation). IRPip1 indicates combination of IR (ionizing $\gamma$-radiation) and piperine $12.5 \mu \mathrm{g} / \mathrm{mL}$. (B) Combination index (CI) plot and $\mathrm{Cl}$ table depict that $\mathrm{Cl}$ value for the chosen combination treatment (IR+Pip $12.5 \mu \mathrm{g} / \mathrm{mL}$ ) is $<1$. (C) Normalized isobologram of the combination treatment (IR+Pip $12.5 \mu \mathrm{g} / \mathrm{mL}$ ). (D) Dose response curve of piperine (Pip) and ionizing $\gamma$-radiation (IR), IRPip2 indicates combination of IR (ionizing $\gamma$-radiation) and piperine $25 \mu \mathrm{g} / \mathrm{mL}$. (E) Cl plot and $\mathrm{Cl}$ table show that $\mathrm{Cl}$ value for the chosen combination treatment (ionizing $\gamma$-radiation (IR)+Pip $12.5 \mu \mathrm{g} / \mathrm{mL}$ ) is $<1$. (F) Normalized isobologram of the combination treatment (ionizing $\gamma$-radiation (IR)+ Pip $25 \mu \mathrm{g} / \mathrm{mL}$ ). 

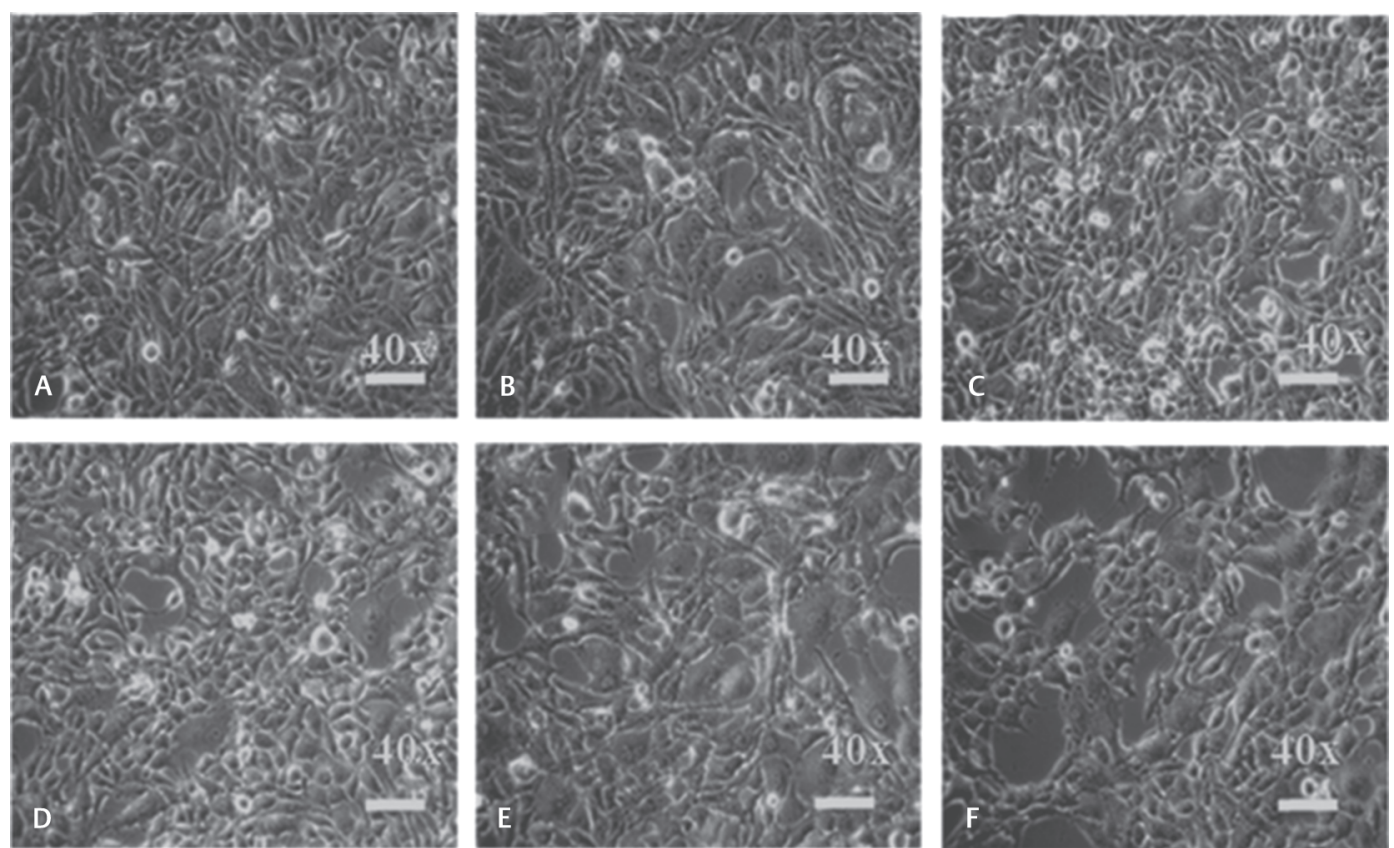

Fig. 3 Morphological analysis of A549 cells after combination treatment with piperine (Pip) and ionizing $\gamma$-radiation (IR), where (A) Sham control, (B) IR, (C) Pip $12.5 \mu \mathrm{g} / \mathrm{mL}$, (D) Pip $25 \mu \mathrm{g} / \mathrm{mL}$, (E) IR+ Pip $12.5 \mu \mathrm{g} / \mathrm{mL}$, and (F) IR+ Pip $25 \mu \mathrm{g} / \mathrm{mL}$.

characteristic features of apoptosis, including disappearance colony formation and appearance of cell shrinkage. The low-dose radiation along with piperine treatment strategy results suggests that piperine pretreatment may improve the treatment strategy by decreasing the dose of radiation treatment that is necessary to suppress the augmentation of lung cancer cells.

\section{Discussion}

Accumulating literature data on in vitro and in vivo activities of piperine show that piperine has immunomodulatory and antiallergic, anti-inflammatory, enhanced drug bioavailability potential, antimutagenic on healthy cells. ${ }^{28,29}$ Cytotoxic effect is selective toward cancer cells. ${ }^{30-32}$ In the present study, we observe piperine as a new compound for reducing the lung cancer proliferation and reveal a novel radiosensitization method of lung cancer via increased inhibition of cell proliferation after piperine pretreatment prior to the radiation treatment. Furthermore, we identify the role of piperine in tumor inhibition with radiation treatment being synergistic in nature. Our results provide new strategic insight into the radiosensitization of lung cancer and suggest that piperine may be an ideal tumor suppressor compound and can be used in radiosensitization in lung cancer treatment.

Programmed cell death or apoptosis is a target of antitumor therapy. Chemo/radiotherapy and phytocompounds like piperine induce the generation reactive oxygen species (ROS) leading to DNA damage and cell cycle arrest. DNA damage may lead to mitochondria-mediated intrinsic pathway of apoptosis. ${ }^{26,33}$ Accumulating evidence has suggested that mechanisms significance to radiosensitivity include programmed cell death or apoptosis through inhibition of cell proliferation with characteristic morphological changes, alteration of cell cycle, inducing DNA damage and inhibition of repair pathways, and alteration of tumor immune microenvironment. $26,34,35$ Studies have shown the targeting DNA damage response, double-strand break repair, and other molecular responses induced cell inactivation by radiation could hold a great approach for radiosensitization. ${ }^{36}$ The experimental data indicate that the combination treatments augmented the cell death compared with individual regime. To study whether the combination effect is synergistic or addictive, $\mathrm{CI}$ analysis was performed. It clearly demonstrates that the combinatorial effect is synergistic in nature for the selected dose of individual regime. The $\mathrm{CI}$ theorem is based on the physical, chemical, and mathematical principles of the mass-action $\mathrm{law}^{37,38}$ and the $\mathrm{Cl}$ equation. ${ }^{37,39}$ Although the mechanisms of each drug are valuable to know, it is not essential to know the mechanism of each drug for studying the synergism or antagonism. ${ }^{37}$ The mechanism of synergistic action after the treatment with piperine and radiation may be due to enhanced DNA damage and cell cycle arrest through induction of ROS that may alter mitochondrial membrane potential leading to apoptosis as observed in our earlier studies with colon cancer cells ${ }^{26}$ and other cancer cell line studies. ${ }^{40}$ These findings have unique significance, as piperine may have the potential to be developed as a radiosensitizing against lung cancer cells.

\section{Conclusion}

The in vitro radiosensitization potential of piperine was elucidated on A549 lung cancer cells in combination with $\gamma$-radiation. Compusyn analysis shows that the combination treatment is synergistic in nature. This investigation on piperine revealed a basic knowledge on combinatory effect of piperine and $\gamma$-radiation on A549 cells. More studies are 
warranted to understand the molecular mechanism of the radiosensitizing action of piperine.

\section{Conflict of Interest}

D.L.M. is supported with research grant/065-2018, Yenepoya (deemed to be University). S.K. is supported by ICMR-SRF, Govt. of India.

\section{Acknowledgment}

The authors would like to thank Prof. Somashekarappa H.M., Director, Centre for Application of Radioisotopes and Radiation Technology (CARRT), Mangalore University, Karnataka, India, for providing $\gamma$-radiation facility.

\section{References}

1 Wang S, Zimmermann S, Parikh K, Mansfield AS, Adjei AA. Current diagnosis and management of small-cell lung cancer. Mayo Clin Proc 2019;94(8):1599-1622

2 Bray F, Ferlay J, Soerjomataram I, Siegel RL, Torre LA, Jemal A. Global cancer statistics 2018: GLOBOCAN estimates of incidence and mortality worldwide for 36 cancers in 185 countries. CA Cancer J Clin 2018;68(6):394-424

3 Spratt DE, Wu AJ, Adeseye V, et al. Recurrence patterns and second primary lung cancers after stereotactic body radiation therapy for early-stage non-small-cell lung cancer: implications for surveillance. Clin Lung Cancer 2016;17(3):177-183. e2, e172

4 Zhao Y, Wang L, Huang Q et al. Radiosensitization of non-small cell lung cancer cells by inhibition of TGF$\beta 1$ signaling with SB431542 is dependent on p53 status. Oncol Res 2016;24(1):1-7

5 Gupta S, Koru-Sengul T, Arnold SM, Devi GR, Mohiuddin M, Ahmed MM. Low-dose fractionated radiation potentiates the effects of cisplatin independent of the hyper-radiation sensitivity in human lung cancer cells. Mol Cancer Ther 2011;10(2):292-302

6 Kuo WT, Tsai YC, Wu HC, et al. Radiosensitization of non-small cell lung cancer by kaempferol. Oncol Rep 2015;34(5):2351-2356

7 Morgan MA, Parsels LA, Maybaum J, Lawrence TS. Improving the efficacy of chemoradiation with targeted agents. Cancer Discov 2014;4(3):280-291

8 Bose S, Banerjee S, Mondal A, et al. Targeting the JAK/STAT signaling pathway using phytocompounds for cancer prevention and therapy. Cells 2020;9(6):E1451

9 Iqbal J, Abbasi BA, Batool R, et al. Potential phytocompounds for developing breast cancer therapeutics: nature's healing touch. Eur J Pharmacol 2018;827:125-148

10 Pistollato F, Calderón Iglesias R, Ruiz R, et al. The use of natural compounds for the targeting and chemoprevention of ovarian cancer. Cancer Lett 2017;411:191-200

11 Ho ST, Tung YT, Kuo YH, Lin CC, Wu JH. Ferruginol inhibits non-small cell lung cancer growth by inducing caspase-associated apoptosis. Integr Cancer Ther 2015;14(1):86-97

12 Szejk M, Kołodziejczyk-Czepas J, Żbikowska HM. Radioprotectors in radiotherapy - advances in the potential application of phytochemicals. Postepy Hig Med Dosw 2016;70(0):722-734

13 Nicholson DW, Ali A, Thornberry NA, et al. Identification and inhibition of the ICE/CED-3 protease necessary for mammalian apoptosis. Nature 1995;376(6535):37-43
14 Cao HY, Ding RL, Li M, et al. Danshensu, a major water-soluble component of Salvia miltiorrhiza, enhances the radioresponse for Lewis lung carcinoma xenografts in mice. Oncol Lett 2017;13(2):605-612

15 Javvadi P, Segan AT, Tuttle SW, Koumenis C. The chemopreventive agent curcumin is a potent radiosensitizer of human cervical tumor cells via increased reactive oxygen species production and overactivation of the mitogen-activated protein kinase pathway. Mol Pharmacol 2008;73(5):1491-1501

16 Lagerweij T, Hiddingh L, Biesmans D, et al. A chemical screen for medulloblastoma identifies quercetin as a putative radiosensitizer. Oncotarget 2016;7(24):35776-35788

17 Ortiz T, Lopez S, Burguillos MA, Edreira A, Piñero J. Radiosensitizer effect of wortmannin in radioresistant bladder tumoral cell lines. Int J Oncol 2004;24(1):169-175

18 Tang Q, Ma J, Sun J, et al. Genistein and AG1024 synergistically increase the radiosensitivity of prostate cancer cells. Oncol Rep 2018;40(2):579-588

19 Khan M, Maryam A, Mehmood T, Zhang Y, Ma T. Enhancing activity of anticancer drugs in multidrug resistant tumors by modulating P-glycoprotein through dietary nutraceuticals. Asian Pac J Cancer Prev 2015;16(16):6831-6839

20 Li H, Krstin S, Wang S, Wink M. Capsaicin and piperine can overcome multidrug resistance in cancer cells to doxorubicin. Molecules 2018;23(3):E557

21 Manayi A, Nabavi SM, Setzer WN, Jafari S. Piperine as a potential anti-cancer agent: a review on preclinical studies. Curr Med Chem 2018;25(37):4918-4928

22 Syed SB, Arya $\mathrm{H}$, Fu IH, et al. Targeting P-glycoprotein: Investigation of piperine analogs for overcoming drug resistance in cancer. Sci Rep 2017;7(1):7972

23 Bolat ZB, Islek Z, Demir BN, Yilmaz EN, Sahin F, Ucisik MH. Curcumin- and piperine-loaded emulsomes as combinational treatment approach enhance the anticancer activity of curcumin on HCT116 colorectal cancer model. Front Bioeng Biotechnol 2020;8:50

24 Chou TC. Drug combination studies and their synergy quantification using the Chou-Talalay method. Cancer Res 2010;70(2):440-446

25 Tolosa L, Donato MT, Gómez-Lechón MJ. General cytotoxicity assessment by means of the MTT assay. Methods Mol Biol 2015;1250:333-348

26 Shaheer K, Somashekarappa HM, Lakshmanan MD. Piperine sensitizes radiation-resistant cancer cells towards radiation and promotes intrinsic pathway of apoptosis. J Food Sci 2020;85(11):4070-4079

27 Chou TC, Talalay P. Quantitative analysis of dose-effect relationships: the combined effects of multiple drugs or enzyme inhibitors. Adv Enzyme Regul 1984;22:27-55

28 Bang JS, Oh DH, Choi HM, et al. Anti-inflammatory and antiarthritic effects of piperine in human interleukin 1beta-stimulated fibroblast-like synoviocytes and in rat arthritis models. Arthritis Res Ther 2009;11(2):R49

29 Stojanović-Radić ZP, Dimitrijević M, Aleksić A, et al. Piperine-a major principle of black pepper: a review of its bioactivity and studies. Appl Sci (Basel) 2019;(9):4270

30 Do MT, Kim HG, Choi JH, et al. Antitumor efficacy of piperine in the treatment of human HER2-overexpressing breast cancer cells. Food Chem 2013;141(3):2591-2599

31 Yaffe PB, Power Coombs MR, Doucette CD, Walsh M, Hoskin DW. Piperine, an alkaloid from black pepper, inhibits growth of human colon cancer cells via G1 arrest and apoptosis triggered by endoplasmic reticulum stress. Mol Carcinog 2015;54(10):1070-1085 
32 Jafri A, Siddiqui S, Rais J, et al. Induction of apoptosis by piperine in human cervical adenocarcinoma via ROS mediated mitochondrial pathway and caspase-3 activation. EXCLI J 2019;18:154-164

33 Pistritto G, Trisciuoglio D, Ceci C, Garufi A, D’Orazi G. Apoptosis as anticancer mechanism: function and dysfunction of its modulators and targeted therapeutic strategies. Aging (Albany NY) 2016;8(4):603-619

34 Huang RX, Zhou PK. DNA damage response signaling pathways and targets for radiotherapy sensitization in cancer. Signal Transduct Target Ther 2020;5(1):60

35 Ozpiskin OM, Zhang L, Li JJ. Immune targets in the tumor microenvironment treated by radiotherapy. Theranostics 2019;9(5):1215-1231
36 Carrano AV. Chromosome aberrations and radiation-induced cell death. II. Predicted and observed cell survival. Mutat Res 1973;17(3):355-366

37 Chou TC. Theoretical basis, experimental design, and computerized simulation of synergism and antagonism in drug combination studies. Pharmacol Rev 2006;58(3):621-681

38 Chou TC. The mass-action law based algorithms for quantitative econo-green bio-research. Integr Biol 2011;3(5):548-559

39 Chou TC. Frequently asked questions in drug combinations and the mass-action law-based answers. Synergy. 2014;(1):3-21

40 Fofaria NM, Kim SH, Srivastava SK. Piperine causes G1 phase cell cycle arrest and apoptosis in melanoma cells through checkpoint kinase-1 activation. PLoS One 2014;9(5):e94298 